\title{
Klassisk medfødt binyrebarkhyperplasi
}

\author{
Medfødt binyrebarkhyperplasi skyldes arvelige enzymdefekter i binyre- \\ barken. Den klassiske formen medfører redusert produksjon av kortisol \\ og aldosteron og samtidig økt produksjon av binyrebarkandrogener. \\ Dette gir virilisering av jenter og binyrebarksvikt og tidlig pubertet hos \\ begge kjønn. I denne artikkelen beskriver vi genetikk, klinisk bilde, dia- \\ gnostikk og behandling.
}

Medfødt binyrebarkhyperplasi skyldes enzymsvikt i binyrebarkens steroidsyntese. Hos over $95 \%$ av pasientene er det mutasjoner i CYP21A2-genet som gir redusert aktivitet i 21 -hydroksylaseenzymet. Svikt i dette enzymet medfører redusert produksjon av aldosteron og kortisol, og konsekvensen blir økt utskilling av adrenokortikotropt hormon (ACTH) fra hypofysen. Dermed stimuleres syntesen av binyrebarkandrogener, som er uavhengig av 21-hydroksylase, med opphopning av 17-hydroksyprogesteron, androstenedion og testosteron (fig 1). I tillegg finnes en rekke sjeldnere enzymdefekter med ulik fenotype.

Klassisk medfødt binyrebarkhyperplasi er vanligste årsak til usikkert kjønn ved fødselen, fordi jenter blir virilisert i fosterlivet (1). Ikke-klassisk medfødt binyrebarkhyperplasi skyldes milde mutasjoner som ikke gir kortisol- eller aldosteronmangel, men hyperandrogenisme hos voksne kvinner. Denne artikkelen omhandler den klassiske formen.

Artikkelen er basert på forfatternes egen forskning og erfaringer og nyere internasjonal litteratur.

\section{Epidemiologi og genetikk}

Basert på nyfødtscreening er insidensen av klassisk binyrebarkhyperplasi om lag 1/15 000 på verdensbasis, men det er stor variasjon mellom folkegrupper (1). I Sverige, der man innførte nyfødtscreening i 1986, er insidensen 1/8 900 (2). I Norge er insidensen beregnet til $1 / 16000$, det vil si om lag fire nye barn i året (3).

Sykdommen arves recessivt, og korrelasjonen mellom genotype og klinisk fenotype er høy.

\section{Klinisk presentasjon}

Medfødt binyrebarkhyperplasi inndeles klassiske og ikke-klassiske former (tab 1) (4, 5), hvorav den klassiske omfatter salttapende og ikke-salttapende form. Ved den salttapende formen er enzymaktiviteten svært lav, noe som medfører både aldosteron- og kortisolmangel. Den salttapende formen debuterer som binyrebarkkrise, med opp- kast, dehydrering, hypoglykemi og hypotensjon samt uttalt hyperkalemi og hyponatremi i de første ukene etter fødselen. Ved den ikke-salttapende formen er en viss enzymfunksjon bevart, slik at aldosteronproduksjonen er tilstrekkelig for å hindre salttap og kortisolmangelen er noe nedsatt.

Ved begge formene blir jenter født med virilisering av de ytre kjønnsorganene. Vanligvis er dette mest uttalt ved den salttapende formen. Karakteriske funn er forstørret klitoris, delvis sammenvokste små kjønnslepper og en felles urogenital sinus. De indre kjønnsorganene, som livmor og eggstokker, er normale. Før nyfødtscreeningen ble innført, ble de fleste jenter med medfødt binyrebarkhyperplasi diagnostisert i nyfødtperioden, men forsinket diagnose og feiltolket somatisk kjønn har forekommet.

Ubehandlet vil jenter gjennomgå stemmeskiftet, bli betydelig virilisert og kortvokste. Prenatal androgeneksponering hos jenter kan føre til maskulin kjønnsrolleatferd (6). Guttene får tidlig pubertet og kan være ferdig utvokst allerede i syv års alder.

\section{Nyfødtscreening og diagnostikk}

Vanlig ultralydundersøkelse i svangerskapet fanger ikke opp tilstanden, men fra 2012 har medfødt binyrebarkhyperplasi vært inkludert i nyfødtscreeningen i Norge. Testen gjennomføres ved å måle 17-hydroksyprogesteron i blod på filterpapir tidligst 48 timer etter fødselen. Målet er å forhindre neonatal død, fastsette kjønnet og forhindre tidlig pubertet.

Etter at nyfødtscreening ble innført i Sverige, er det blitt diagnostisert flere med salttapende form, og flere overlever (2).

\section{Behandling}

\section{Generell behandling og oppfølging}

Oppfølgingen av pasientene rettes mot både hormonelle og psykologiske forhold i alle stadier av livet. Hos nyfødte er problemstillingene særlig knyttet til diagnostikk, kjønnsfastsettelse og det å unngå binyrebarkkriser. veisinfeksjon hos jenter, og det kan være
I spedbarnsalderen er det risiko for urin-

\section{Ingrid Nermoen}

ingrid.nermoen@ahus.no

Endokrinologisk avdeling

Akershus universitetssykehus

og

Campus Ahus

Institutt for klinisk medisin

Universitetet i Oslo

Eystein S. Husebye

Medisinsk avdeling

Haukeland universitetssykehus

og

Klinisk institutt 2

Universitetet i Bergen

Anne Grethe Myhre*

Barne-og ungdomsklinikken

Oslo universitetssykehus, Rikshospitalet

\section{Kristian Løvås}

Medisinsk avdeling

Haukeland universitetssykehus

og

Klinisk institutt 2

Universitetet i Bergen

* Nåværende adresse:

Frambu kompetansesenter for sjeldne diagnoser

Engelsk oversettelse på www.tidsskriftet.no

\section{HOVEDBUDSKAP}

Medfødt binyrebarkhyperplasi er en sjelden arvelig sykdom hvor enzymaktiviteten i binyrebarken er nedsatt

Sykdommen medfører redusert kortisolog aldosteronproduksjon og virilisering av jenter

Behandlingen er en balanse mellom substitusjon og suppresjon av glukokortikoid og mineralkortikoid. Overbehandling med glukokortikoid bør unngås

Pasientene bør ha norsk steroidkort og få opplæring i å gi seg selv hydrokortison (Solu-Cortef) intramuskulært ved kriser 
$3 \beta$-hydroksysteroiddehydrogenase
$11 \beta$-hydroksylase (CYP11 $\beta 2$ )

18-hydroksylase (CYP11 $\beta 2$ )

18-oksidase (CYP11ß2)

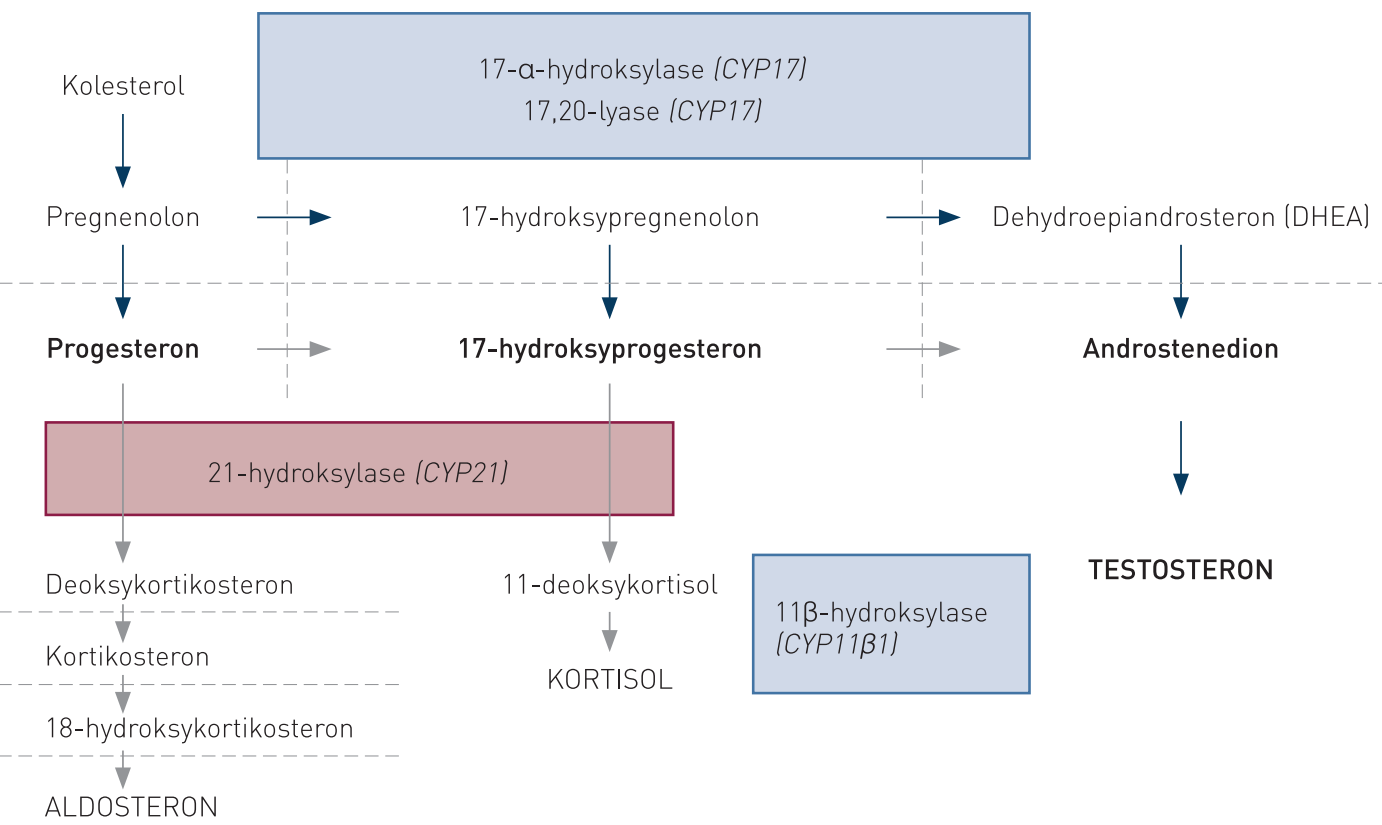

Figur 1 Medfødt binyrebarkhyperplasi skyldes arvelige enzymdefekter i binyrebarken. Den røde boksen viser 21-hydroksylaseenzymet, og CYP21A2 er det muterte genet. De blå boksene viser sjeldne enzymdefekter med tilsvarende CYP-gen

behov for genital kirurgi. Barn følges tett opp i barneavdelinger med særskilt kompetanse på substitusjonsterapi med steroider. Jenter med medfødt binyrebarkhyperplasi og deres familier skal ha tilbud om oppfølging $\mathrm{i}$ et multidisiplinært team bestående av barnelege, barnekirurg, psykolog/psykiater og gynekolog frem til voksen alder.

Voksne med medfødt binyrebarkhyperplasi bør følges av endokrinolog. Hensikten med den medikamentelle behandlingen er å substituere de livsnødvendige hormonene aldosteron og kortisol samt supprimere ACTH-produksjonen, slik at nivåene av binyrebarkandrogener reduseres. Optimal behandling vil hindre ACTH-stimulert vekst av binyrene og utvikling av godartede svulster.

Hyperandrogenisme hos kvinnene medfører uregelmessige menstruasjoner og infertilitet, som kan bedres ved riktig behandling med kortikosteroider. Til tross for problemene med virilisering har kun $40 \%$ av norske kvinner med medfødt binyrebarkhyperplasi vært til gynekologisk undersøkelse i voksen alder (3).

\section{Glukokortikoider}

I behandlingen av disse pasientene er særlig balansen mellom substitusjon og suppresjon krevende. Dosen som kreves for suppresjon, må ofte være høyere enn det som er nødvendig substitusjonsdose. Dette innebærer økt risiko for bivirkninger som overvekt, metabolsk syndrom, veksthemming og osteopeni. Behandlingen monitoreres ved måling av veksthastighet og benkjernealder hos barn og måling av 17-hydroksyprogesteron- nivå. Verdien bør ligge like over referanseområdet for å unngå overbehandling.

De naturlige glukokortikoidene kortison og hydrokortison (kortisol) har kort virketid og gir dermed ikke ACTH-suppresjon på etternatten. For å oppveie dette og sikre tilstrekkelig suppresjon gjennom hele døgnet kan syntetiske glukokortikoider som prednisolon og deksametason gis om kvelden, men disse gir samtidig økt risiko for overdosering og anbefales ikke til barn i vekst. Denne behandlingen gjenskaper dessverre ikke den normale døgnprofilen av kortisol, og medikamenter med modifisert frisetting av hydrokortison er under utvikling (7). Kontinuerlig subkutan hydrokortisoninfusjon kan være nyttig hos enkelte pasienter (8).
Det finnes egne internasjonale retningslinjer for glukokortikoidbehandling hos barn. Disse anbefaler hydrokortison, som gir minst risiko for hemming av lengdeveksten (9). For voksne finnes det ikke internasjonale retningslinjer (4). Vi anbefaler kortisonacetat (Cortison tabletter) $25-37,5 \mathrm{mg}$, fordelt på 2-3 doser, eventuelt med tillegg av prednisolon 2,5 $\mathrm{mg}$ om kvelden.

\section{Viktig opplæring}

Det er viktig at pasientene er klar over at de må øke dosene ved akutt sykdom - for å unngå binyrebarkkriser. Alle bør ha fått utlevert norsk steroidkort og må få opplæring i å gi seg selv hydrokortison (Solu-Cortef) intramuskulært ved kriser (10).

Tabell 1 Inndeling av 21-hydroksylasemangeltilstander $(4,5)$ (modifisert). $\downarrow=$ nedsatt $\downarrow \downarrow=$ ingen produksjon

\begin{tabular}{|c|c|c|c|}
\hline \multirow[b]{2}{*}{ Karakteristika } & \multicolumn{2}{|c|}{ Klassisk type } & \multirow[t]{2}{*}{ Ikke-klassisk type } \\
\hline & Salttapende & Ikke salttapende & \\
\hline $\begin{array}{l}\text { Alder ved } \\
\text { diagnosetidspunkt }\end{array}$ & Nyfødtperioden & $\begin{array}{l}\text { Nyfødtperioden (kvinner) } \\
\text { eller barndom (menn) }\end{array}$ & $\begin{array}{l}\text { Fra småbarnsalder } \\
\text { til voksen alder }\end{array}$ \\
\hline Virilisering/hirsutisme & Moderat til uttalt & Moderat til uttalt & $\begin{array}{l}\text { Ingen til lett og moderat, } \\
\text { kan få tidlig pubertet }\end{array}$ \\
\hline Prosent enzymaktivitet & 0 & $1-10 \%$ & $30-75 \%$ \\
\hline Aldosteron & $\downarrow \downarrow$ & $\downarrow$ Normal & Normal \\
\hline Kortisol & $\downarrow \downarrow$ & $\downarrow$ & Normal \\
\hline
\end{tabular}

1 I land med nyfødtscreening, som Norge, stilles diagnosen klassisk medfødt binyrebarkhyperplasi i nyfødtperioden 


\section{Mineralkortikoider}

Fludrokortison (Florinef) er eneste tilgjengelige mineralkortikoid og anbefales til alle barn med medfødt binyrebarkhyperplasi (9). Etter avsluttet lengdevekst kan mange med ikke-salttapende form klare seg uten fludrokortison, men det kan være nyttig å fortsette med medikamentet, fordi dette kan medføre mindre behov for glukokortikoider. I Norge bruker voksne pasienter mindre fludrokortison enn i andre land (3). Dosen varierer fra $50 \mu \mathrm{g}$ til $200 \mu \mathrm{g}$ daglig, uavhengig av kroppsstørrelse, gitt i én dose.

Stort saltbehov og ortostatisk blodtrykksfall tyder på underdosering. Dosen vurderes ut fra blodtrykk, elektrolytter og plasmarenin-aktivitet, som bør være i øvre del av normalområdet eller like over. Det er viktig å informere pasientene om betydningen av et tilstrekkelig saltinntak.

\section{Psykososial oppfølging}

Foreldre som får et barn der det er usikkerhet omkring kjønnet, vil som regel oppleve dette som svært vanskelig. Derfor er det opprettet en nasjonal behandlingstjeneste med tverrfaglige team ved Oslo universitetssykehus og Haukeland universitetssykehus som skal stå for initial utredning og behandling av disse barna.

Voksne kvinner med medfødt binyrebarkhyperplasi kan oppleve økt psykologisk stress, blant annet på grunn av tidligere genital kirurgi, maskulin kjønnsrolleatferd, spørsmål om seksualitet, amenoré, fertilitet og identitet, og bør tilbys psykologisk oppfølging.

\section{Klinisk forløp}

Høyde

Voksne med medfødt binyrebarkhyperplasi er lavere enn normalbefolkningen, både på grunn av androgendrevet tidlig pubertet og veksthemming som følge av overdosering med glukokortikoider. Median slutthøyde for norske kvinner og menn ligger henholdsvis $6,3 \mathrm{~cm}$ og $11,2 \mathrm{~cm}$ under medianhøyden i den øvrige befolkningen (11).

Kroppssammensetning, bentetthet og brudd Glukokortikoider øker fettmassen og reduserer muskelmassen og bentettheten, mens androgener har motsatt effekt. I mange studier er det rapportert høy kroppsmasseindeks hos både barn, ungdommer og voksne med medfødt binyrebarkhyperplasi $(12,13)$. Vi fant at disse har høyere fettmasse enn den øvrige populasjonen, spesielt gjelder dette yngre kvinner (11). Studier med voksne har også vist at disse pasientene har redusert bentetthet $(11,12)$.

Kardiovaskulær sykdom og annen sykdom I en nyere svensk registerstudie var forekomsten av kardiovaskulære og metabolske sykdommer nesten fire ganger så høy som i den øvrige befolkningen hos pasienter med medfødt binyrebarkhyperplasi (OR 3,9; $95 \% \mathrm{KI} 3,1-5,0)$. I tillegg var det økt forekomst av hypertensjon, atrieflimmer, venøs tromboembolisme, fedme, type 2-diabetes og obstruktiv søvnapné (14).

\section{Binyre- og testikkelsvulster}

Pasientene er utsatt for å utvikle binyresvulster, spesielt myelolipomer (15). Myelolipomer er benigne, inhomogene og fettrike svulster som sjelden krever kirurgisk behandling. Ved tilfeldig funn av binyresvulster og ved binyrebarkhyperplasi er medfødt binyrebarkhyperplasi en differensialdiagnose. Flere eldre norske menn har fått diagnostisert klassisk binyrebarkhyperplasi etter tilfeldig funn av store binyrer ved CT abdomen.

Menn med medfødt binyrebarkhyperplasi har økt risiko for testikulære adrenale resttumorer. Dette er benigne svulster i testiklene utgått fra ektopisk binyrevev, som vokser under langvarig økt ACTH-stimulering (16). I en norsk studie med 23 menn med medfødt binyrebarkhyperplasi hadde $57 \%$ av dem med den salttapende formen slike svulster, men ingen med den ikke-salttapende formen (15).

Dersom disse resttumorene blir store, kan de medføre obstruktiv azoospermi og irreversibel skade på testikkelparenkymet, med fibrose, gonadedysfunksjon og infertilitet (16). Lokaliseringen av tumor nær rete testis gjør at de kan være vanskelige å oppdage ved klinisk undersøkelse, og regelmessig ultralydundersøkelse av testiklene er foreslått som rutine $(4,9)$

\section{Fertilitet}

Det er rapportert lave graviditetsrater hos kvinner med medfødt binyrebarkhyperplasi, spesielt gjelder det dem med den salttapende formen (3). Mange faktorer kan bidra til dette, slik som virilisering av eksterne genitalia, oligo- og amenoré og anovulasjon. Hos kvinnene er det også økt forekomst av homoseksuell legning og status som enslig (17).

Fertiliteten hos menn med medfødt binyrebarkhyperplasi kan være fra normal til betydelig nedsatt, og det er kjent at testikulære adrenale resttumorer kan medføre redusert fertilitet (16).

\section{Helserelatert livskvalitet}

I undersøkelser av helserelatert livskvalitet er det ulike resultater, men de største studiene, fra Norge, Storbritannia og Tyskland, viser signifikant lavere livskvalitet enn i den øvrige befolkningen $(3,12,18)$.

\section{Konklusjon}

Medfødt binyrebarkhyperplasi er en sykdom med flere problemområder som krever spesialisert og multidisiplinær oppfølging. Hor- monbehandlingen er en krevende balansegang mellom under- og overdosering.

Pasientene rapporterer redusert livskvalitet, og tilstanden medfører flere psykologiske utfordringer. Fastleger og andre leger som behandler voksne pasienter med medfødt binyrebarkhyperplasi, bør sikre at disse får oppfølging hos spesialist.

\section{Ingrid Nermoen (f. 1962)}

er spesialist i indremedisin og i endokrinologi, overlege og førsteamanuensis. Hun har forsket på medfødt binyrebarkhyperplasi (CAH) i Norge. Forfatter har fylt ut ICMJE-skjemaet og oppgir ingen interessekonflikter.

\section{Eystein Sverre Husebye (f. 1961)}

er spesialist i indremedisin og i endokrinologi, overlege og professor. Han er også gjesteprofessor ved Institutionen för Medicin, Karolinska institutet, Solna. Forskningsfeltet er vesentlig kliniske studier og eksperimentelle studier av binyrens endokrinologi, spesielt binyrebarksvikt og polyendokrine syndromer.

Forfatter har fylt ut ICMJE-skjemaet og oppgir følgende interessekonflikter: Han har mottatt foredragshonorar fra Shire.

\section{Anne Grethe Myhre (f. 1959)}

er spesialist i barnesykdommer, med spisskompetanse i endokrinologi, og overlege. Hun har en doktorgrad i autoimmune binyrebarksyndromer, er medlem av Nasjonal studiegruppe for Addisons sykdom og har vært leder av Flerregional behandlingstjeneste for usikker somatisk kjønnsutvikling ved Oslo universitetssykehus.

Forfatter har fylt ut ICMJE-skjemaet og oppgir ingen interessekonflikter.

\section{Kristian Løvås (f. 1968)}

er spesialist $\mathrm{i}$ indremedisin og i endokrinologi. professor II og overlege. Forskningsfeltet er vesentlig kliniske studier av binyrebarksvikt, inklusive medfødt binyrebarkhyperplasi (CAH). Han har deltatt i oppstarten av et internasjonalt register for $\mathrm{CAH}$ (www.i-cah.org).

Forfatter har fylt ut ICMJE-skjemaet og oppgir ingen interessekonflikter.

Litteratur

Pang S. Newborn screening for congenital adrenal hyperplasia. Pediatr Ann 2003; 32: 516-23.

2. Gidlöf S, Falhammar H, Thilén A et al. One hundred years of congenital adrenal hyperplasia in Sweden a retrospective, population-based cohort study. Lancet Diabetes Endocrinol 2013; 1: 35-42.

3. Nermoen I, Husebye ES, Svartberg J et al. Subjective health status in men and women with congenital adrenal hyperplasia: a population-based survey in Norway. Eur J Endocrinol 2010; 163: 453-9.

4. Speiser PW, Azziz R, Baskin LS et al. Congenital adrenal hyperplasia due to steroid 21-hydroxylase deficiency: an Endocrine Society clinical practice guideline. J Clin Endocrinol Metab 2010; 95: 4133-60. 
5. Wedell A, Thilén A, Ritzén EM et al. Mutational spectrum of the steroid 21-hydroxylase gene in Sweden: implications for genetic diagnosis and association with disease manifestation. J Clin Endocrinol Metab 1994; 78: 1145-52.

6. Diseth TH. Barn født med uklare kjønnskarakteristika. Tidsskr Nor Legeforen 2008: 128: 576-80.

7. Mallappa A, Sinaii N, Kumar P et al. A phase 2 study of Chronocort, a modified-release formulation of hydrocortisone, in the treatment of adults with classic congenital adrenal hyperplasia. J Clin Endocrinol Metab 2015; 100: 1137-45.

8. Nella AA, Mallappa A, Perritt AF et al. A Phase 2 Study of Continuous Subcutaneous Hydrocortisone Infusion in Adults With Congenital Adrenal Hyperplasia. J Clin Endocrinol Metab 2016; 101: 4690-8.

9. Clayton PE, Miller WL, Oberfield SE et al. Consensus statement on 21-hydroxylase deficiency from the European Society for Paediatric Endocrinology and the Lawson Wilkins Pediatric Endocrine Society. Horm Res 2002; 58: 188-95.

10. Husebye ES, Erichsen MM, Myhre AG et al. Nytt steroidkort ved binyrebarksvikt. Tidsskr Nor Legeforen 2012; 132: 2043-4

11. Nermoen I, Brønstad I, Fougner KJ et al. Genetic, anthropometric and metabolic features of adult Norwegian patients with 21-hydroxylase deficiency. Eur J Endocrinol 2012; 167: 507-16

12. Arlt W, Willis DS, Wild SH et al. Health status of adults with congenital adrenal hyperplasia: a cohort study of 203 patients. J Clin Endocrinol Metab 2010; 95: 5110-21.

13. Völkl TM, Simm D, Beier C et al. Obesity among children and adolescents with classic congenital adrenal hyperplasia due to 21-hydroxylase deficiency. Pediatrics 2006; 117: e98-105.

14. Falhammar H, Frisén L, Hirschberg AL et al. Increased Cardiovascular and Metabolic Morbidity in Patients With 21-Hydroxylase Deficiency: A Swedish Population-Based National Cohort Study. J Clin Endocrinol Metab 2015; 100: 3520-8.

15. Nermoen I, Rørvik J, Holmedal SH et al. High frequency of adrenal myelolipomas and testicular adrenal rest tumours in adult Norwegian patients with classical congenital adrenal hyperplasia because of 21-hydroxylase deficiency. Clin Endocrinol (Oxf) 2011; 75: 753-9.

16. Stikkelbroeck NM, Otten BJ, Pasic A et al. High prevalence of testicular adrenal rest tumors, impaired spermatogenesis, and Leydig cell failure in adolescent and adult males with congenital adrenal hyperplasia. J Clin Endocrinol Metab 2001; 86: $5721-8$.

17. Frisén L, Nordenström A, Falhammar $\mathrm{H}$ et al. Gender role behavior, sexuality, and psychosocial adaptation in women with congenital adrenal hyperplasia due to CYP21A2 deficiency. J Clin Endocrinol Metab 2009; 94: 3432-9.

18. Reisch N. Hahner S, Bleicken B et al. Quality of life is less impaired in adults with congenital adrenal hyperplasia because of 21-hydroxylase deficiency than in patients with primary adrenal insufficiency. Clin Endocrinol (Oxf) 2011; 74: 166-73.

Mottatt 22.5. 2016, første revisjon innsendt 14.10. 2016, godkjent 3.1. 2017. Redaktør: Mette Kalager. 